\title{
Simple and Rapid Detection of Garlic Latent Virus from Welsh Onions by Gelatin Particle Agglutination Test
}

\author{
Masanobu FuKami*, Keiko T. Natsuaki**, Fusao Motoyoshi*** \\ and Keiichi TOMARU**
}

Key words: garlic latent virus, particle agglutination test, non-specific reaction.

Seedless Welsh onion (Allium fistulosum L.) called "Bozushirazu" is cultivated widely in Chiba Prefecture, Japan. Mosaic and stripe symptoms which may be caused by viruses are commonly observed on the leaves of seedless Welsh onions. Most of the seedless Welsh onions are known to be infected with at least two viruses, onion yellow dwarf virus (OYDV; Potyvirus) and garlic latent virus (GLV; Carlavirus). OYDV induces mosaic and stripe symptoms, whereas GLV induces no visible symptoms in Welsh onion seedlings. However, GLV infection causes growth retardation when Welsh onion seedlings are doubly infected with OYDV (Isamu Sako, personal communication). Occurrence of GLV on the seedless Welsh onions in Chiba Prefecture has been known since $1987^{1}$.

Virus-free plants of strawberry, carnation and seedless Welsh onion are produced using a method of meristem tip culture and propagated in Chiba-ken Foundation Seed and Stock Farm $^{2}$. Since seedless Welsh onions carrying GLV exhibited no visible symptoms, a simple and rapid assay method is required to ascertain whether each individual plant is virus-free or not. The gelatin particle agglutination test (PA test $)^{3)}$ has been known to be a simple and rapid technique for detecting plant viruses ${ }^{4}$. In this method, artificial gelatin particle carriers coated with antiserum or $\gamma$-globulin are used. In the present study, we examined an application of the PA test for detection of GLV.

GLV was purified using the method described by Huttinga ${ }^{5)}$ from naturally infected seedless Welsh onions collected from fields in Matsudo City. For antiserum production, a rabbit was injected with emulsions of equal volumes of virus and Freund's complete adjuvant into the muscles three times at 8-14 day intervals. Twenty one days later, blood was collected. The anti-GLV serum had a titer of $1 / 128$ dilution in the ring test. Anti-GLV $\gamma$-globulin, which was partially purified from the antiserum by ammonium sulfate-precipitation was used in this study. A GLV isolate (No. 3-6) was obtained through single lesion isolation transfers of more than ten times, using leaves of Chenopodium quinoa Willd. with $0.3 \mathrm{M}$ dipotassium hydrogenphosphate as the extractant. The isolate was maintained in inoculated Welsh onion seedlings (cv. Kyotokujo) in a glasshouse for more than one year. The leaf tissues of these infected plants

* Chiba Agricultural Experiment Station, 808 Daizenno, Chiba, Chiba 280-02, Japan 千葉県 農業試験場

** Faculty of Agriculture, Tokyo University of Agriculture, Sakuragaoka, Setagaya-ku, Tokyo 156, Japan 東京農業大学農学部

*** National Institute of Agrobiological Resources, Kannondai, Tsukuba, Ibaraki 305, Japan 農 林水産省農業生物資源研究所

1) Fukami, M., Motoyoshi, F. and Honda, Y. (1987). Proc. Kanto Pl. Prot. Soc. 34: 79-80. 2) Ohkoshi, K., Ishii, K. and Jitsukawa, S. (1987). Bull. Chiba Found. Seed \& St. Farm 9:1-10. 3) Ikeda, M., Fujino, R., Matsui, T., Yoshida, T., Komoda, H. and Imai, J. (1984). Gann 75: 845-848. 4) Natsuaki, K.T., Nishimura, Y., Ikeda, M. and Tomaru, K. (1988). Ann. Phytopath. Soc. Japan 54: 548551. 5) Huttinga, H. (1975). Neth. J. Pl. Path. 81: 81-83. 
were ground with mortar and pestle, in $0.1 \mathrm{M}$ phosphate buffered saline, $\mathrm{pH} 7.2$, containing $0.1 \%$ bovine serum albumin and $0.02 \%$ sodium azide (PBS-BSA) and the extract was used as a material for the PA test. Samples of seedless Welsh onions collected from fields in Matsudo City were similarly prepared and used for mass-screening test. Artificial gelatin particle (supplied by Fuji Rebio Inc.) and PBS-BSA were used for the PA test procedure. Purified preparations of GLV serially diluted with PBS-BSA and both extracts from the Welsh onion seedlings (cv. Kyotokujo) and from seedless Welsh onions infected with GLV were used as samples for detecting virus antigen. Procedure for coating of gelatin particles with $\gamma$-globulin and PA test with virus antigens were performed as described by Natsuaki et al. ${ }^{4)}$

A test was carried out for optimizing concentration of anti-GLV $\gamma$-globulin to coat the gelatin particles. The gelatin particles were coated with the $\gamma$-globulin at concentrations varying from 50 to $200 \mu \mathrm{g} / \mathrm{ml}$ and reacted with several different concentrations of purified virus. The most clear reaction occurred at the $50 \mu \mathrm{g} / \mathrm{ml}$ coating concentration and the dilution end point was $0.1 \mu \mathrm{g} / \mathrm{ml}$ with purified virus preparation. At the coating concentrations of 100 and $200 \mu \mathrm{g} / \mathrm{ml}$, some non-specific agglutination was observed and the dilution end points of the virus were not clear, as shown in Fig. 1. The non-specific agglutination may also occur when plant tissue extracts are assayed using the gelatin particle coated with a high concentration of $\gamma$-globulin. The coating concentration of $50 \mu \mathrm{g} / \mathrm{ml}$ is optimum, as far as tested, for practical use. The particles coated at this concentration were thus used in all the following experiments.

Before the Welsh onion seedling tissue extract was used for the GLV detection, the extract was filtered through a paper towel, but non-specific reaction sometimes could not be removed, especially at lower dilutions of healthy leaf sap. This non-specific reaction may be caused by the high content of mucilage in Welsh onions. Addition of polyvinyl pyrrolidone (1-4\%), hemicellulase $(0.1-1 \%)$ or nicotine $(1-5 \%)$ to PBS-BSA as extraction buffer did not decrease the non-specific reaction. The use of supernatant after centrifugation at $16,100 \times g$ for $5 \mathrm{~min}$, however, remarkably reduced the non-specific reaction without any change in the reaction end point (Fig. 2). This procedure was thus employed in all the following experiments.

Concentration of anti-GLV $\gamma$-globulin for coating gelatin particles $(\mu \mathrm{g} / \mathrm{ml})$
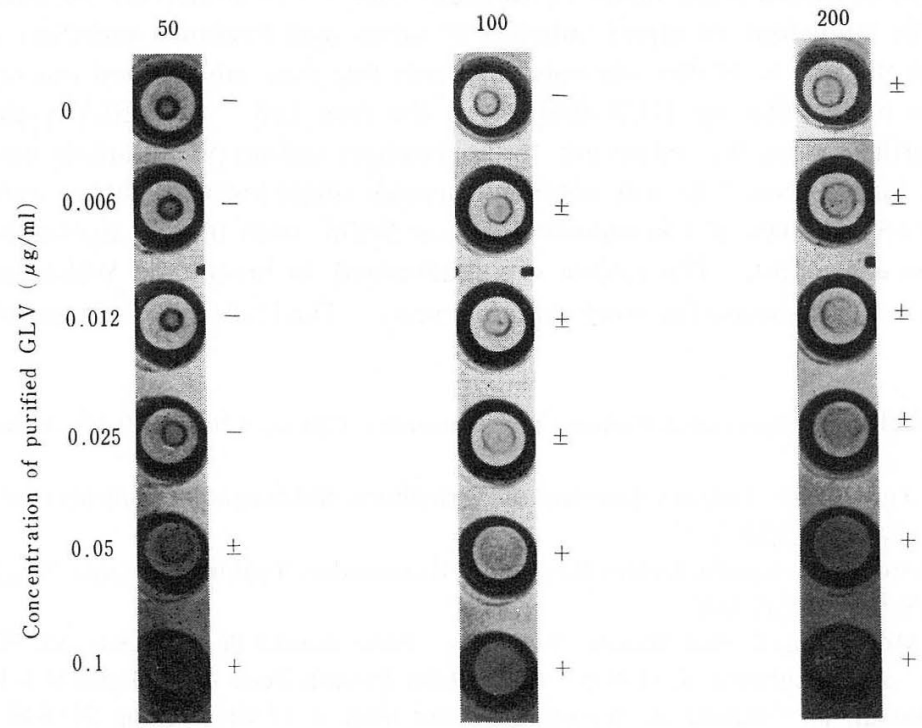

Fig. 1. PA test of purified GLV. PA test: +, positive reaction; -, negative reaction; \pm , quasi-positive reaction. 
In the next experiment, the sampling position of the Welsh onion seedling was examined. Samples for detection of GLV were collected from the youngest leaf, an old (4th from the youngest leaf) leaf and roots of one infected plant. In the youngest leaf, GLV was detected at the highest dilutions of extracts, while in the old leaf or the roots negative reaction was sometimes observed even at the lower dilutions (Table 1). The sensitivity of reaction to antigen was higher in the extract of the youngest leaf than in the extracts of other parts of the plant. The young leaf was, thus, the best as a sample.

The sensitivity of the PA test was compared with that of the bioassay using Chenopodium amaranticolor Coste et Reynier. Bioassay was performed as follows: The leaves of GLV-infected Welsh onion seedling (cv. Kyotokujo) were ground by mortar and pestle and diluted serially with $0.01 \mathrm{M}$ phosphate buffer, $\mathrm{pH}$ 7.2. The extract was mechanically inoculated to

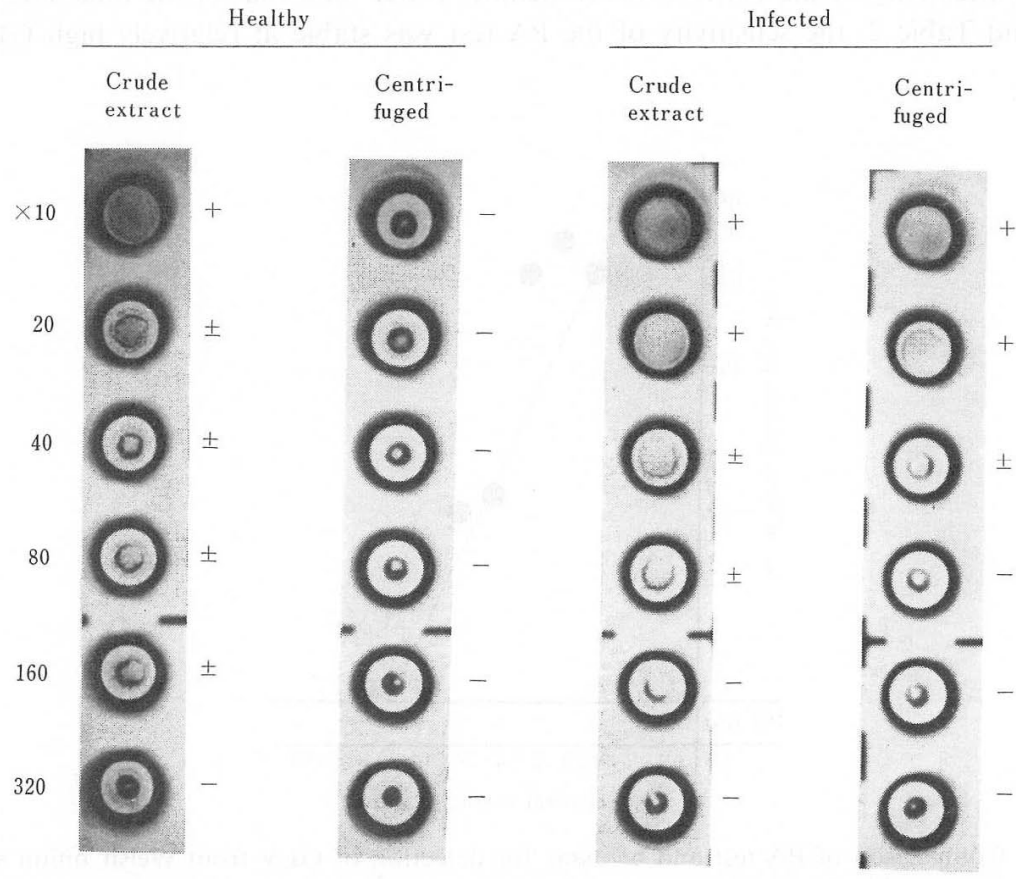

Fig. 2. Decrease of non-specific reaction in PA test after low-speed centrifugation of leaf extract from Welsh onion seedling. PA test: see footnote in Fig. 1. Welsh onion seedlings were grown in a glasshouse in the winter.

Table 1. PA test of GLV on different positions of Welsh onion seedlings

\begin{tabular}{|c|c|c|c|c|c|c|}
\hline \multirow{2}{*}{$\begin{array}{l}\text { Reciprocal } \\
\text { extract } \\
\text { dilution }\end{array}$} & \multicolumn{3}{|c|}{ Healthy } & \multicolumn{3}{|c|}{ Infected } \\
\hline & Youngest leaf & Old leafa) & Root & Youngest leaf & old leaf & Root \\
\hline$\times 10$ & - b) & - & - & + & - & \pm \\
\hline 20 & - & - & - & + & - & \pm \\
\hline 40 & - & - & - & + & 一 & - \\
\hline 80 & - & - & - & + & - & - \\
\hline 160 & - & - & - & \pm & - & - \\
\hline 320 & - & - & - & - & - & - \\
\hline
\end{tabular}

a) Fourth from the youngest leaf.

b) See footnote in Fig. 1. Welsh onion seedlings were grown in a glasshouse in the winter. 
leaves of C. amaranticolor, which were dusted with carborundum, at 10- to 12-leaf stage. Local lesions that developed on the 5, 6 and 7th leaf from the lowest leaf, were counted at 11 days after inoculation. Two plants were tested at each dilution. PA test was also performed using the same GLV-infected leaf. In this experiment, dilution end points of the leaf extract were 1/1,600 with PA test and 1/6,400 with bioassay. It is not conclusive, however, that the PA test was less sensitive than the bioassay, since in bioassay, numbers of local lesions per leaf were very few in the extract diluted higher than 1/400 (Fig. 3). An attempt to detect to GLV in the Welsh onions collected in the fields was carried out by PA test, immunosorbent electron microscopy (ISEM, clump method $\left.{ }^{6}\right)$ ) and bioassay. Bioassay was performed as described above, except that the extracts were diluted to $1 / 10$ and that one test plant was used for each sample. In sample No. 3 of Table 2, GLV was detected by the ISEM and the PA test, but not by the bioassay (Table 2). The result in the bioassay at a low concentration of GLV seemed to be less confidencial. Though the sensitivity of the PA test was sometimes lower than that of the bioassay, as a results of Fig. 3 and Table 2, the sensitivity of the PA test was stable at relatively high GLV concentrations.

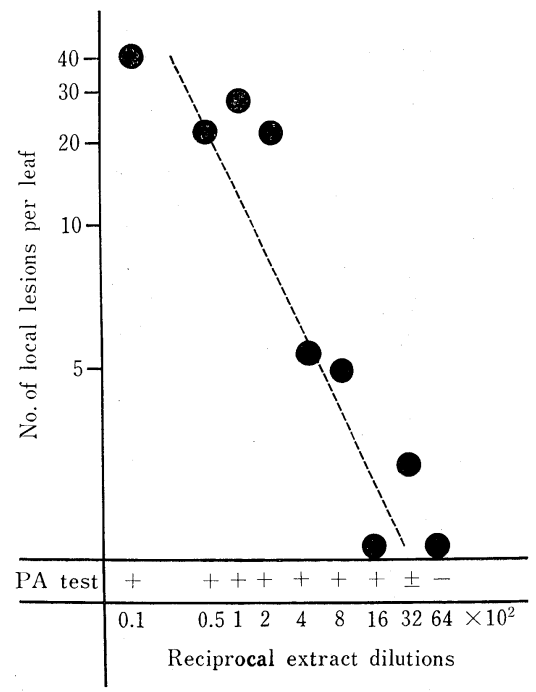

Fig. 3. Comparison of PA test and bioassay for detection of GLV from Welsh onion seedling. PA test: see footnote in Fig. 1. Bioassay: values are average number of local lesions per leaf of two plants. Welsh onion seedlings were grown in glasshouse in the autumn.

Table 2. Comparison of results in GLV detection by PA test, ISEM and bioassay in field samples

\begin{tabular}{|c|c|c|c|c|c|c|c|c|c|c|}
\hline \multirow{2}{*}{$\begin{array}{l}\text { Assay } \\
\text { system }\end{array}$} & \multicolumn{10}{|c|}{ Samplea) No. } \\
\hline & 1 & 2 & 3 & 4 & 5 & 6 & 7 & 8 & 9 & 10 \\
\hline PA test $\mathrm{b}$ ) & + & - & + & + & - & - & + & - & - & - \\
\hline ISEM $^{\mathrm{c}}$ ) & + & - & + & + & - & - & + & - & - & - \\
\hline Bioassay d) & 3.3 & 0 & 0 & 0.3 & 0 & 0 & 1 & 0 & 0 & 0 \\
\hline
\end{tabular}

a) Samples were collected from fields in the winter.

b) See footnote in Fig. 1. The extracts were diluted to 1/10.

c) ISEM: $+=$ positive; $-=$ negative.

d) Values are average number of local lesions per leaf of Chenopodium amaranticolor.

6) Milne, R.G. and Luisoni, E. (1977). Methods in Virology, Vol. 6. Academic Press, New York. pp. 265-281. 
Table 3. Mass-screening of GLV with PA test and ISEM

\begin{tabular}{cccc}
\hline \multirow{2}{*}{ ISEM } & PA test $a)$ & \multicolumn{2}{c}{ No. of samples } \\
\cline { 3 - 4 } & & $\begin{array}{c}\text { Inoculated Welsh } \\
\text { onion seedling }\end{array}$ & $\begin{array}{c}\text { Seedless Welsh onion } \\
\text { collected in the field }\end{array}$ \\
- & - & 11 & 7 \\
+ & $+/ \pm$ & 7 & 1 \\
+ & - & 0 & 0 \\
\hline Total & 35 & 34 \\
\hline
\end{tabular}

a) See footnote in Table 2, and Fig. 1.

The possibility of mass-screening using PA test was surveyed. Young leaves of 53 Welsh onion seedlings which had been artificially inoculated and 42 seedless Welsh onions collected in fields were used for the test. All the samples which were confirmed as positive by the ISEM were positive or quasi-positive by the PA test. Some negative samples by the ISEM showed positive reaction by the PA test (Table 3). As a result of the mass-screening test, we confirmed that the PA test can be used for detection of GLV in the field-grown seedless Welsh onions. In Fig. 2, Tables 1 and 2, the reaction end points of infected plant extracts in the PA test or the number of local lesions in bioassay, respectively, were lower than those in Fig. 3. The reason for these differences may have been that the plants used in Fig. 2 and Tables 1 and 2 were grown in a glasshouse or collected from fields in the winter and multiplications of GLV in these plants were reduced at low temperature in this season.

Bioassay requires at least 5 days, many test plants and a glasshouse to grow them in. ISEM is considerably laborious and an electron microscope is necessary. PA test is quicker, easier and simpler than the former methods, and requires no expensive equipment. PA test is thus useful for routine GLV detection.

We thank Ms. Y. Nishimura and Mr. M. Ikeda, Fuji Rebio Inc., for supplying gelatin particles. We also thank Dr. A. Fujiie, Chiba Agricultural Experiment Station, for critical reading of the manuscript.

\section{和 文 摘 要}

深見正信・夏秋啓子・本吉総男・都丸敬一 : ゼラチン粒子凝集法によるニンニク潜在ウイルスのネギから の検出

ゼラチン粒子凝集法（PA 法）によりニンニク潜在ウイルス（GLV）のネギからの検出を試みた。粒子 に感作する抗体の濃度を $50 \mu \mathrm{g} / \mathrm{ml}$ にすることにより, 純化ウイルスに対して明膫な反応がみられた。感染 葉磨砕液を $16,100 \times g$ で 5 分間遠心分離し，その上清を用いることにより，ネギからの検出時にみられる 非特異反応を感度の低下なしに低減させることがでさた。ネギの部位別の反応は新しく生長しつつある葉が 最も高い検出限界を示した。PA 法の検出限界は純化ウイルスに対しては, $0.1 \mu \mathrm{g} / \mathrm{ml}$, 葉磨哗液では 1,600 倍であり, 生物検定に比べて劣る場合もあったが, ウイルス濃度が比較的高い場合には PA 法の感度は安定 していた。GLV を接種したネギおよび围場から採集したネギからの検出を行ったところ，免疫電顕法で感 染が確認されたすべての株から GLV を検出できた。 